\title{
RANKING OF DAILY SATELLITE-DERIVED PRECIPITATION EXTREMES FOR THE ORBIG PIPELINE IN RIO DE JANEIRO
}

\author{
I. C.F. Amaral ${ }^{1 *}$, R. S. Libonati ${ }^{1}$, A. C. P. A. Palmeira ${ }^{1}$ \\ ${ }^{1}$ Institute of Geosciences, Dept. of Meteorology, Federal University of Rio de Janeiro, Rio de Janeiro, Brazil -
}

(igor.amara1006,anactn)@gmail.com - renata.libonati@igeo.ufrj.br

KEY WORDS: GPM, Precipitation extremes, Remote sensing, Rio de Janeiro, Pipeline.

\begin{abstract}
:
The present work was motivated by the occurrence of vast damage caused by intense rainfalls in the state of Rio de Janeiro and the great importance of the oil pipelines for the economy by using remote sensing multisatellite dataset from the GPM 3-IMERG-HHE product from 06/2000 to 06/2019, along the ORBIG pipeline located between the municipalities of Angra dos Reis and Duque de Caxias, RJ. A statistical ranking method has been applied to classify extreme daily precipitation events over the region. An event is classified as extreme by considering the total affected area and its intensity, based on the daily normalized anomaly calculated from the climatology data. The results show that in cold front events the oil pipeline region is hit more spatially with high accumulations of daily precipitation. However, in thermal instability precipitation, despite affecting locally, it has also shown extreme precipitation events, highlighting that in the 10 largest cases there were no false alarms, according to records found in news reports and rainfall indexes. It was also noted that during summer time there were more extreme cases. In conclusion, this study served to indicate places and times of higher rainfall index regardless of whether the region has a dense population or not.
\end{abstract}

\section{INTRODUCTION}

The rupture of the pipelines that cross rural and urban regions in the state of Rio de Janeiro can have significant consequences for the environment and the population. In Brazil, oil pipelines have a high risk of failure due to geological and precipitation causes (Esford et al., 2004).

According to André et al. (2008), in the state of Rio de Janeiro, there are different precipitation regimes that depend on the region, which are characterized by mountainous centers and / or close to urban centers. Research relating extremes of precipitation in these locations to landslides and floods is of great importance to mitigate their impacts.

For accurate analysis of extremes of precipitation, the input data must have high resolution and low uncertainty level. The precipitation shows small-scale variability that requires frequent inspections and adequate spatial representation. Such inspections are not possible through in situ measurements, especially in the oceans and remote or underdeveloped regions. Furthermore, flaws in the precipitation station network data sets make them unsuitable for the study of extremes. Thus, remote sensing techniques should be used to overcome these problems due to their adequate temporal and spatial resolution and their global coverage.

Therefore, the objective of this study is to identify and rank extreme precipitation around the ORBIG pipeline region using satellite information (Figure 1 and 2). The methodology focuses on the Global Precipitation Measurement (GPM) multisatellite dataset over the last two decades. It is noteworthy that rankings were defined regardless of the occurrence of significant socioeconomic impacts. The events were characterized by high daily precipitation that have influenced relatively large areas.

\section{DATASET AND ANALYSIS}

Precipitation data was obtained for the period between 06/2000 and 06/2019 through the GPM hydroestimators, Huffman et. al. (2019), using the 3B-HHR-E product from Integrated Multisatellite Retrievals (IMERG) version 06B.

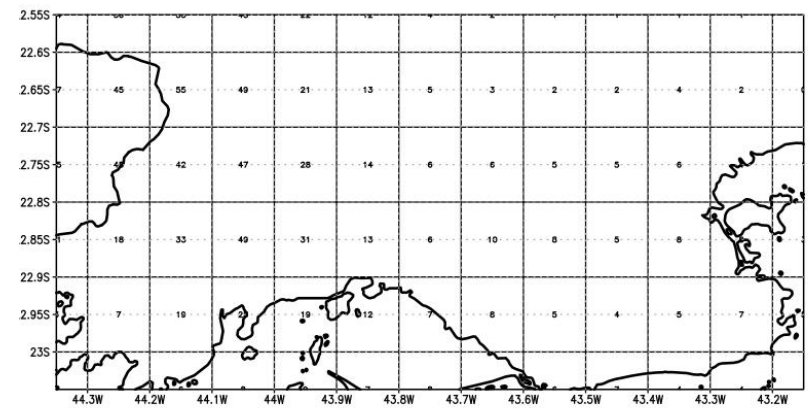

Figure 1 . The study region location latitudes $22^{\circ} 55^{\prime} 56^{\prime \prime} \mathrm{S}, 23^{\circ}$ $05^{\prime} 08^{\prime \prime} \mathrm{S}$ and longitudes $043^{\circ} 15^{\prime} 23^{\prime \prime} \mathrm{W}, 044^{\circ} 35^{\prime} 19^{\prime \prime} \mathrm{W}$.

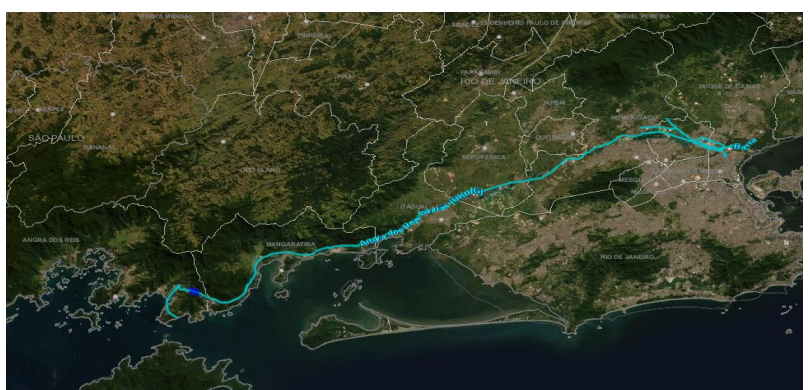

Figure 2. Location of pipeline ORBIG and surrounding region.

The precipitation estimates for the various passive microwave satellite sensors (PMW) that make up the GPM constellation are

\footnotetext{
* Igor Cunha França do Amaral
} 
calculated using the 2017 version of the Goddard Profiling Algorithm (GPROF2017), interleaved with the combined radar algorithm and GPM $\mathrm{Ku}$ radiometer, and fused in half an hour fields at $0.1^{\circ} \mathrm{x} 0.1^{\circ}$ (approximately $10 \times 10 \mathrm{~km}$ ).

Precipitation estimates calculated from the various passive microwave satellite sensors are intercalibrated with the CORRA product Final change is then made, combined with geo-IR fields calibrated by microwave precipitation to provide rainfall estimates every half hour all around the world.

To identify extreme precipitation event, we followed the work of Ramos et. al. (2014), where each extreme event was classified according to the total daily amount of precipitation in each grid cell and the proportion of the affected areas. The method applied to characterize and classify the severity of precipitation and its spatial extent of each extreme day is described below:

$$
\mathrm{N}=(\operatorname{prec}-\mu) / \sigma
$$

where $\quad \mathrm{N}$ - is the standardized anomaly

Prec - is the daily precipitation

$\mu$ - is the climatological mean daily precipitation $\sigma-$ is the respective standard deviation

The reference period for calculating the climatological average and standard deviation was the entire period from $06 / 2000$ to $06 / 2019$. We took into account only days with daily precipitation above $1 \mathrm{~mm}$ masking the ocean.

To highlight the levels of highest intensity of precipitation, we calculated the rarity index of each event (R) given by:

$$
\mathrm{R}=\mathrm{A} \times \mathrm{M}
$$

Where $\mathrm{A}$ is the area (in percent) with standard deviation precipitation anomalies above 2 and $\mathrm{M}$ is the spatial average of these anomalies for all points in the grid that are characterized by precipitation anomalies standard deviation above 2 .

\section{RESULTS}

In this work, we have identified the 10 major extreme events from 2000 to 2019 over the study period (Table 1). In addition, the final index $\mathrm{R}=\mathrm{A} \times \mathrm{M}$ used to rank the days has been calculated. In that region, a majority of extreme rain events occurred from 2001 to 2011, and only one event occurred after that period, in 2018. It is worth noting that most of the top 10 events took place during the southern summer, with the exception of the 2018 event that took place in August (southern winter). Particularly the following cases: 2nd (January 3rd, 2008), 3rd (March 29, 2001) and 4th (August 3, 2018) corresponded to cases with significant disasters and victims over the region.

\begin{tabular}{|c|c|c|c|c|}
\hline Date & $\begin{array}{c}\text { Precipitation } \\
(\mathrm{mm})\end{array}$ & $\mathrm{A}$ & $\mathrm{M}$ & $\mathrm{R}$ \\
\hline $2008-01-05$ & 396.3 & 98.7 & 6.1 & 607.5 \\
$2008-02-03$ & 236.9 & 100.0 & 3.5 & 354.3 \\
$2001-03-29$ & 371.8 & 75.6 & 3.3 & 250.7 \\
$2018-08-03$ & 184.3 & 97.4 & 2.5 & 247.2 \\
$2009-12-31$ & 226.2 & 96.1 & 2.3 & 224.9 \\
$2006-02-10$ & 276.3 & 98.7 & 2.2 & 218.5 \\
$2009-03-13$ & 276.5 & 83.3 & 2.5 & 216.3 \\
$2010-03-14$ & 309.4 & 66.6 & 2.9 & 199.7 \\
$2011-01-11$ & 184.5 & 100.0 & 1.9 & 190.0 \\
$2010-03-15$ & 225.7 & 97.4 & 1.8 & 177.9 \\
\hline
\end{tabular}

Table 1. The ten highest risk precipitation events.

The method was developed to take into consideration two factors, the area of influence of extreme precipitation given by anomalies above the threshold, and the intensity of the event given by the average values of the anomalies, which become more visible in the analysis of the top 3 events in the domain. The first event (1st) in the rank corresponds to January 5, 2008, where generalized and intense precipitation occurs in the western part of the domain, along with some intense precipitation in some other parts (Figure 3).

In terms of the synoptic pattern, these days are characterized by a deep low-pressure system with a cold core located over Rio de Janeiro, with its associated fronts crossing the region. This synoptic configuration led to an advection of hot and humid air, which associated with cold air, caused a very deep convection and, consequently, an intense precipitation, Barcellos (2009).

The second top ranked event corresponds to February 3, 2008 (Figure 4), a broader event ( $\mathrm{A}=100 \%$ of the domain) characterized by an extensive precipitation range covering the entire region, with significant socioeconomic impacts, i.e., nine deaths, Pereira et. al. (2008). This event was due to a rapidly deepening cyclone, this configuration implied a substantial increase in atmospheric instability and consequently triggered a strong convection that played a key role in the development of convective system, according to Barcellos et. al. (2016).

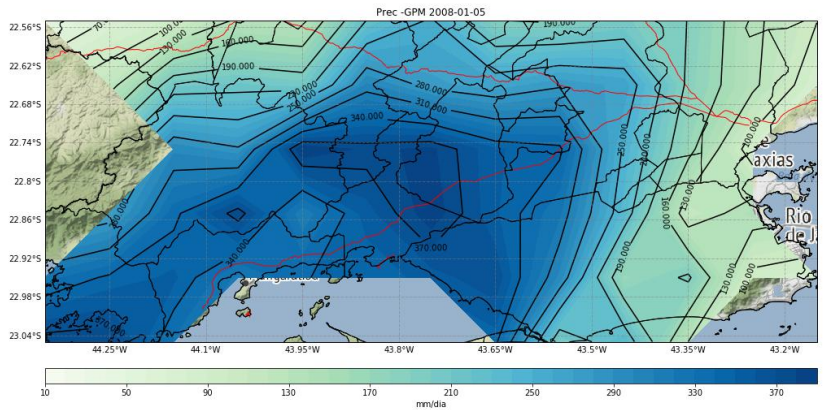

Figure 3. Accumulated daily rainfall shown as shaded and black contour lines with red lines representing pipeline transmissions. Date 2008-01-05.

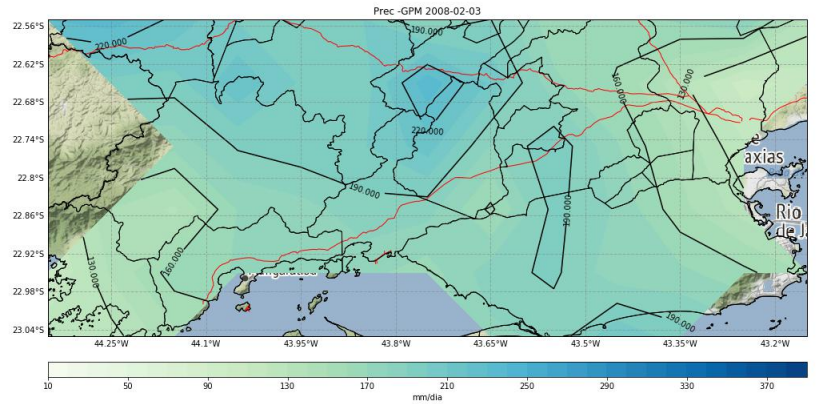

Figure 4. Accumulated daily rainfall shown as shaded and black contour lines with red lines representing pipeline transmissions. Date 2008-02-03. 


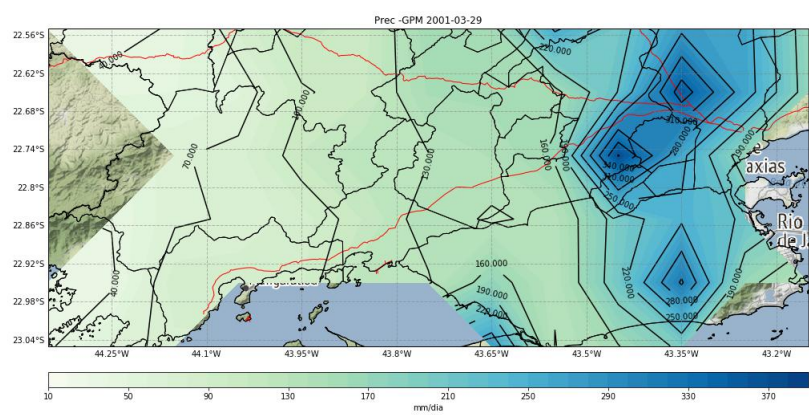

Figure 5. Accumulated daily rainfall shown as shaded and black contour lines with red lines representing pipeline transmissions. Date 2001-03-29.

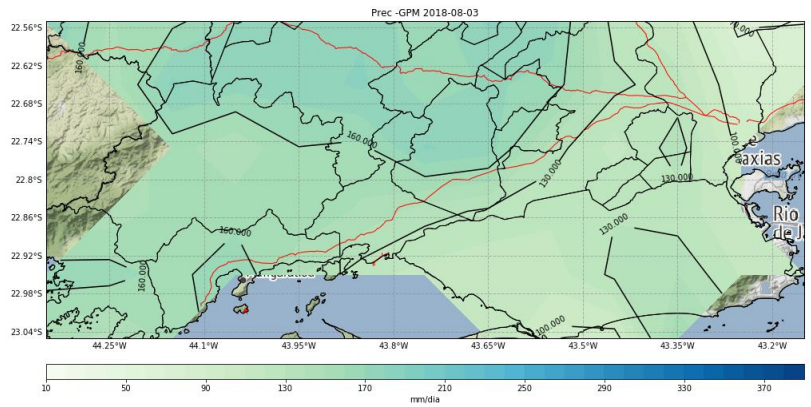

Figure 6. Accumulated daily rainfall shown as shaded and black contour lines with red lines representing pipeline transmissions. Date 2018-08-03.

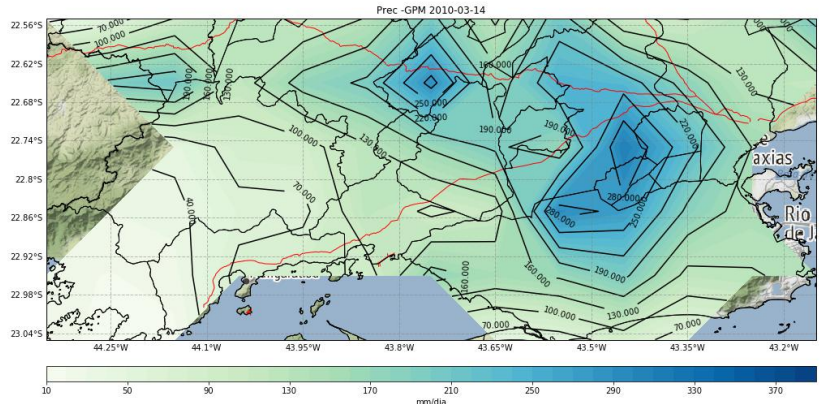

Figure 7. Accumulated daily rainfall on shaded and black contour lines with red lines representing pipeline transmissions. Date 2010-03-14.

The third largest event, March 29, 2001 (Figure 5), corresponds to the event in which the day was characterized by intense precipitation, mainly in the duct region, where the A (M) index reaches about $75.6 \%$ (3.3). Despite its top position for the domain, there is less information about socioeconomic impacts in news and literature, but some landslides did occur. However, the applied method focuses on identifying and characterizing the extreme precipitation values associated with synoptic events, which may or may not cause human fatalities or significant socioeconomic impacts. Nevertheless, it is worth mentioning that some of the extreme episodes of precipitation that caused significant damage and/or death are often associated with extreme precipitation on a local scale. For instance, during the $8^{\text {th }}$ event (Figure 7), March 14-15, 2010, Rio de Janeiro was hit by a high-volume precipitation event, which was immediately followed by generalized urban flooding and landslides as well as human life loss estimated as ten fatalities (Lottermann \& Trigueiro, 2019). These days did not stand out in the classification as they affected a relatively small area (although very intensely). It is also important to note that some of the impacts were exacerbated by the fact that there was substantial precipitation in the week prior to this event.

The fourth and most recent extreme event identified corresponds to the rainy day of August 3, 2018 (Figure 6) with a maximum of $184.3 \mathrm{~mm}$. According to news records, one child died and three were buried in mud. In terms of the ranking, this day was characterized by indexes below those previously mentioned, which explains the 4 th classification $(\mathrm{A}=97.4 \%$ and $\mathrm{M}=2.5$ )

Figures 3, 5 and 7 show the daily accumulation having their centers on the ORBIG pipeline and the consequences, such as landslides and flooding nearby. Although there was no disaster in the pipeline it is clear that the mapping done in this work is of great importance.

\section{CONCLUSIONS}

In this work, we adopted a method to classify extreme precipitation events in Rio de Janeiro. The magnitude of an event is characterized not only by the area affected, but also by its average intensity. In addition, it should be stressed that the establishment of these rankings were independent of the occurrence of significant socioeconomic impacts, as shown by the different examples presented.

The apparent incompatibility between the top positions detected here and the classifications of events that caused major economic damage or human fatalities can be attributed to different issues: (1) the duration of the event is not taken into consideration in the ranking, (2) some of the extreme hydrometeorological events, such as landslides or sudden floods, depend on accumulated weekly and monthly rainfall and saturation of soil moisture, especially to affect the ORBIG pipeline, (3) in general, the risk is due not only to damage to the population but also the value of exposed goods and their vulnerability. In this respect, the areas often characterized by intense rainfall anomalies do not correspond to large populated areas with buildings and transportation networks.

\section{ACKNOWLEDGEMENTS}

Acknowledgements of support of this project: 'Caracterização meteo-oceanográfica e análise de extremos ambientais’, number SIGITEC:2017/00563-6.

\section{REFERENCES}

André, R. G. B., Marques, V., Pinheiro, F. M. A., Ferraudo, A. S., 2008. Identificação de regiões pluviometricamente homogêneas no estado do Rio de Janeiro, utilizando-se valores mensais. Revista Brasileira de Meteorologia, 23(4), 501-509. [In Portuguese.]

Barcellos, P. C. L., 2009. Precipitações Intensas na Cidade do Rio de Janeiro: Probabilidade e Previsibilidade. Dissertation, Universidade Federal do Rio de Janeiro, Brazil. [In Portuguese.]

Barcellos, P. C. L., Silva, F. P., Vissirini, F. S. B., Magalhães, C. A., Terra, J. M., Dutra, M. R. F., Amaral, I. C. F., 2016. Diagnóstico Meteorológico dos Desastres Naturais Ocorridos nos Últimos 20 Anos na Cidade de Duque de Caxias. 2016. 
Revista Brasileira de Meteorologia, 31(3), 319-329. doi.org/10.1590/0102-778631320150146. [In Portuguese.]

Davis, E. G., Naghettini, M. C., 2001. Estudo de Chuvas Intensas no Estado do Rio de Janeiro. CPRM, Minas Gerais, Brazil. [In Portuguese.]

D'orsi, R. N., 2011. Correlação entre pluviometria e escorregamentos no trecho da Serra dos Órgãos da Rodovia Federal BR-116 RJ (Estrada Rio-Teresópolis). Dissertation, Universidade Federal do Rio de Janeiro, Brazil. [In Portuguese.]

Esford, F., Porter, M., Savigny, K. W., Muhlbauer, W. K., Dunlop, C., 2004. A risk assessment model for pipelines exposed to geohazards. 5th International Pipeline Conference, Calgary, Alberta, Canada. doi:10.1115/IPC2004/0327.

Huffman, G. J., Stocker, E. F., Bolvin, D. T., Nelkin, E. J., Tan, J., 2019. GPM IMERG Early Precipitation L3 Half Hourly 0.1 degree x 0.1 degree V06, Greenbelt, MD. Goddard Earth Sciences Data and Information Services Center, GES DISC. doi: 10.5067/GPM/IMERG/3B-HH-E / 06.

Junker, N. W., Grumm, R. H., Hart, R., Bosart, L. F., Bell, K. M., Pereira, F. J., 2008. Use of standardized anomaly fields to anticipate extreme rainfall in the mountains of Northern California. Weather Forecasting. 23(1), 336-356.

Kaspar, M., Muller, M., 2008. Selection of historic heavy largescale rainfall events in the Czech Republic. Natural Hazards and Earth System Sciences. 8(6), 159-1367.

Lottermann, A., Trigueiro, A. M., 2019. Chuva do Rio é a mais forte em 22 anos, Segundo dados do Alerta Rio. Technical report. $\quad<$ https://g1.globo.com/rj/rio-dejaneiro/noticia/2019/04/09/chuva-do-rio-e-a-mais-forte-em-22anos-segundo-dados-do-alerta-rio.ghtml $>$. Accessed 14 August 2010. [In Portuguese.]

Monteiro, J. B., Zanella, M. E., 2014. Eventos pluviométricos extremos e impactos associados em Fortaleza/Brasil: uma análise a partir da técnica dos quantis, quoted in Sillva, C. A., Fialho, E. S., Steinke, E. T., 2014. Experimentos em Climatologia Geográfica. Editora da Universidade Federal da Grande Dourados: UFGD, 165-184. [In Portuguese.]

Oliveira, E. M. G., 2014. Parametrizações convectivas no modelo WRF e sua relação com a precipitação durante ciclogêneses no sudeste da América do Sul. Dissertation, Universidade Federal de Santa Maria, Brazil. [In Portuguese.]

Pereira, M., Spautz, D., Silva, A., 2008. Deslizamentos de terra no Rio deixam nove mortos. Technical report. $<$ https://www.nsctotal.com.br/noticias/deslizamentos-de-terrano-rio-deixam-nove-mortos $>$. Accessed 10 August 2018. [In Portuguese.]

Ramos, A. M., Trigo, R. M., Liberato, M. L. R., 2014. A ranking of high-resolution daily precipitation extreme events for the Iberian Peninsula. Atmos. Sci. Lett., 15(4), 328-334. doi: 10.1002/as12.507. 